\title{
BİTÜMLÜ SICAK KARIŞIMLARDAN GERİ DÖNÜŞÜM YOLU İLE ELDE EDILEN AGREGALARIN PERFORMANSLARININ DEĞERLENDİRILMESİ: DENEYSEL BİR ÇALIŞMA
}

\author{
Sevil KÖFTECİ (ORCID: 0000-0002-5096-2545)* \\ İnşaat Mühendisliği Bölümü, Mühendislik Fakültesi, Akdeniz Üniversitesi, Antalya, Türkiye \\ Geliş / Received: 18.01.2017 \\ Düzeltmelerin gelisis / Received in revised form:23.03.2017 \\ Kabul / Accepted: 24.03.2017
}

\begin{abstract}
ÖZ
Hatalı imalatlar ve benzeri nedenlerle ortaya çıkan atık asfaltlar, büyük çevre kirliliğine neden olmaktadırlar. $\mathrm{Bu}$ makalede, hatalı imalat sonucu ortaya çıkan atık bitümlü sıcak karışımlardan (BSK) elde edilen geri dönüştürülmüş agregaların, temel karakteristik özelliklerinin değerlendirildiği deneysel bir çalışma sunulmuştur. $\mathrm{Bu}$ amaçla, Antalya ilindeki bir yol kesimine ait bitümlü temel tabakasından karot makinesi ile 20 adet numune alınmıştır. Bitümlü sıcak karışımın temel bileşenleri olan agrega ve bitüm, laboratuvarda reflüks (cam) ekstraktörde trikloretilen ile birbirinden ayrıştırılmıştır. Her bir karot numunesindeki agregalara ayrı ayrı elek analizi yapılmış, elde edilen sonuçlar ilgili şartnamedeki bitümlü temel tabakasına ait alt ve üst limit değerler ile karşılaştırılmışıı. Daha sonra, geri kazanılan agregaların yanı sıra yeni kalker ve bazalt agregaların performansları Los Angeles aşınma, yassılık indeksi, soyulma, donma-çözülme ve metilen mavisi deneyleri gibi agrega deneyleri ile analiz edilmiştir. Deneysel testlerden elde edilen sonuçlar, geri kazanım yolu ile elde edilmiş agregaların performanslarının şartname standartlarını karşıladığı, bu nedenle yol üstyapısında tekrar kullanılmasının uygun olduğunu göstermektedir.
\end{abstract}

Anahtar Kelimeler: Atık asfalt, hatalı yol inşaatı, geri dönüştürülmüş agrega, asfaltın ekstraksiyonu, bitümlü temel tabakas1

\section{PERFORMANCE EVALUATION OF RECYCLED AGGREGATES OBTAINED FROM HOT MIX ASPHALT: AN EXPERIMENTAL STUDY}

\begin{abstract}
Waste asphalt pavements occurring from the faulty road construction or similar reasons cause great environmental pollution. This paper presents an experimental study on determination of fundamental characteristics of the recycled aggregates obtained from waste bituminous hot mixtures. For this purpose, 20 drilling core samples from a road segment in Antalya city were taken out by using core drilling machine. Aggregates and bitumen which are the main components of the bituminous hot mixture were separated from each other by using reflux extractor test set. Sieve analysis was performed on the each drilling core samples. Obtained results were compared to the lower and upper limit values of the bituminous base layer according to the related specification. Then, the performance of recycled aggregate, new limestone and basalt aggregates as well were analysed with aggregate tests such as Los Angeles abrasion, flakiness index, stripping resistance, soundness of aggregate by use of magnesium sulfate and methylene blue. According to the results obtained from the experimental tests, it can be said that recycled aggregates meet requirements of asphalt specifications and they can be used as aggregate again in asphalt pavement.
\end{abstract}

Keywords: Waste asphalt, faulty road construction, recycled aggregate, extraction of asphalt, bituminous base layer

"Corresponding author / Sorumlu yazar. Tel.:+90 242310 6366; e-mail / e-posta: skofteci@ akdeniz.edu.tr 


\section{GİRİş}

Esnek yol üstyapılar, günümüzde ülkemizde ve dünyada en çok kullanılan üstyapı tipidir. Esnek yol üstyapı tabakalarını oluşturan bitümlü sıcak karışım (BSK) genel hatları ile şu şekilde üretilmektedir: Kullanılacak bitümün penetrasyonuna göre $145-160{ }^{0} \mathrm{C}^{\prime}$ a kadar ssitılarak kurutulmuş agrega ile agregadan $5{ }^{0} \mathrm{C}$ daha düşük sıcaklıkta 1sıtılarak viskoz sıvı haline getirilmiş bitüm, Karayolları Teknik Şartnamesi'nde [1] belirtilen dizayn kriterlerine uygun olarak bir plentte karıştırılmaktadır. Karışımın ağırlıkça agrega oranı, karışımın kullanılacağı tabaka özelliklerine bağlı olarak değişmekle birlikte, yaklaşık olarak \%95 civarındadır. Karışımda agrega iskelet konumundadır ve tekrarlı trafik yüklerine karşı mukavemet agregalar tarafından sağlanmaktadır [2]. Ülkemizde BSK üretimi sadece 2012 yılında 46 milyon tondur ve ülkemiz BSK üretiminde Avrupa'da 2. siradadır [3]. Bütün bunlar göz önüne alındığında, sadece karayolu inşaatlarında agrega tüketiminin ne kadar büyük miktarlarda olduğu ortaya çıkmaktadır. Agregalar, taş ocaklarından elde edilmekte ve üretilmesi işlemleri doğaya çok zarar vermektedir. Şekil 1'de taş ocaklarının oluşturduğu doğa tahribatı görülmektedir.

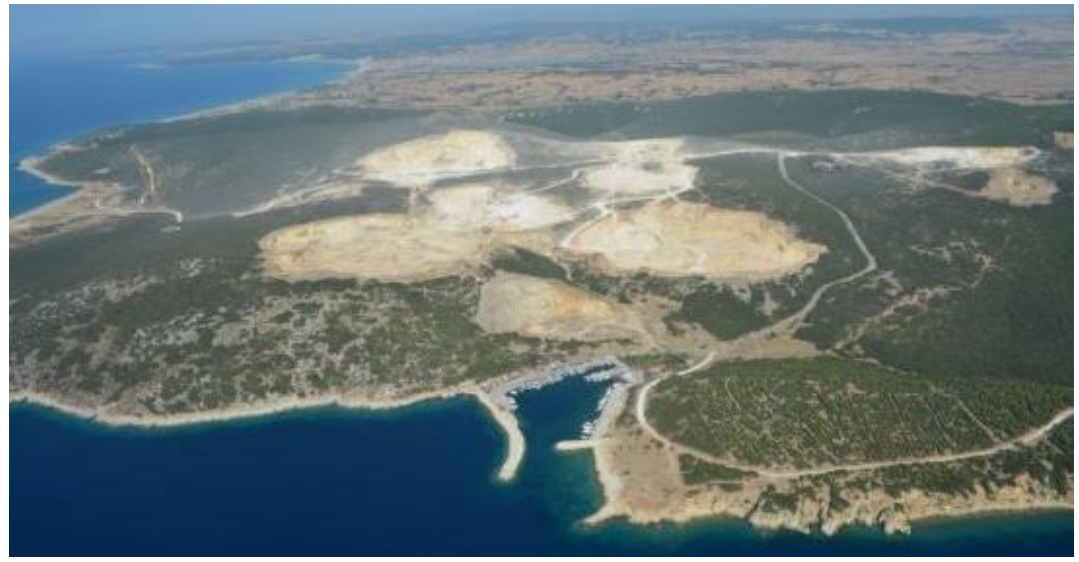

Şekil 1. Saroz Körfezi'nde taş ocaklarının yaptığı doğa tahribatı [4]

Ülkemizde ve dünyada, agrega rezervlerinin hızla tükenmesi, karayolu inşaatlarında yeni arayışlara neden olmaktadır. Atık malzemelerin çeşitli yöntemlerle geri kazanılarak tekrar kullanılabilir hale getirilmesine geri dönüşüm denilmektedir. Özellikle ülkemizde nüfus artışı ile birlikte atık madde miktarı artmış, geri dönüşüm ekonomik bir değer haline gelmiş ve Çevre Bakanlığı tarafından 1991 yılında yayınlanan Katı Atıkların Kontrolü Yönetmeliği ile geri dönüşüm yasal zorunluluk haline gelmiştir [5].

Geri dönüşüm yöntemi ile yol ve bina inşaatlarında daha önce kullanılmış olan agregaların tekrar BSK dizaynına bitümlü veya bitümsüz alarak belli oranlarda sokulması üzerinde son yıllarda en çok çalışılan konulardan birisidir [6-8]. Guo ve ark. [9], laboratuvar çalışmasında RAP içeren 1lık karışım asfalt dizaynları gerçekleştirmiştir. \%0-\%40 aralığında geri dönüşüm asfalt içeren 1lık karışım asfalt numunelerinde, katk1 maddesi olarak Evotherm-DAT ve S-I-WMA kullanmıştır. Yaşlandırılmış karışımlar için neme ve düşük sıcaklık çatlamalarına karşı direnç değeri belirlenmiştir. Deneysel çalışmalar sonucu elde edilen sonuçlara göre, geri dönüşüm asfalt içermeyen 1lık asfalt karışımları düşük sıcaklık çatlamalarına ve neme karşı daha yüksek direnç göstermiştir ancak tekerlek izi dayanımı geri dönüşüm asfalt içeren karışımlara göre daha düşüktür.Nem direnci açısından, geri dönüşüm asfaltlı karışımlarda kısa dönem yaşlanmadaki tahribat uzun dönem yaşlanmaya göre oldukça azdır. Kısa dönem ve uzun dönem yaşlandırılmış 1lık karışım asfalt numunelerinin düşük sıcaklık çatlamalarına karşı direnci ise, yaşlandırılmamış numunelere göre oldukça düşmüştür. İndirekt çekme mukavemeti sonuçlarına göre, geri dönüştürülmüş asfalt eklenmiş 1lık asfalt karışımları üç adet donma-çözünme döngüsünden sonra olumlu özellikler gösterse de döngü sayısı arttıkça olumsuz sonuçlar elde edilmiştir. Ilık asfalt karışımına geri dönüştürülmüş asfalt karışımı eklenmesi, karışımın yorulma direncini belirgin bir şekilde azaltmıştır.

Abreu ve ark. [10], atık asfalt karışımı üretiminde mekanik, çevresel ve ekonomik performansı artırmak amacı ile çeşitli atık materyallerin yüksek oranda kullanım imkanını araştırmışlardır. Çalışma kapsamında ilk olarak geri dönüştürülmüş asfaltın özellikleri incelenmiş, daha sonra katkı maddesi olarak kullanılmış motor yağı ve yüksek yoğunluklu polietilen (HDPE) gibi atıkların bağlayıcıya katkı maddesi olarak kullanılması durumu analiz edilmiş, katkı maddeli ve katkı maddesiz değişik karışımlar üretilmiş ve performansları birbirleri ile karşılaştırılmıştır. Deneysel çalışmalar sonucunda, \% 7,5 oranında kullanılmış motor yağı ve \%4 oranında HDPE atığının bağlayıcı için modifiyer olarak kullanılabileceği belirlenmiştir. Bu modifiyerler, \%50 oranında atık 
asfalt ile kullanıldığında WTS $=0,02 \mathrm{~mm} / 10^{3}$, yorulma direnci $\varepsilon_{\sigma}=160,4$ ve su hassasiyeti ITRS $=\% 81,9$ olan çok başarılı sonuçlar elde edilmiştir. Haritonovs ve ark. [11] tarafindan, Litvanya'da yapılan çalışmada, ilk olarak ekstraksiyon işlemi ile geri dönüştürülmüş asfalt karışımı içerisindeki bağlayıcı ve agregayı ayrıştırılmıştır. Daha sonra, geri dönüşüm yolu ile elde ettiği bağlayıcının penetrasyon, yumuşama noktası ve Frass kırılma noktası değerlerini belirlenmiş̧ir. Daha sonra dolomit agrega kullanılarak 2 çeşit gradasyonda ve bitüm oranında geri dönüştürülmüş asfalt karışımı oluşturulmuştur ve bunlara A6 RAP ve A7 RAP adları verilmiş̧ir. A6 RAP \%30, A7 RAP \%30 ve A7 RAP \%50 oranlarında üç değişik karışım elde edilmiştir. Hamburg tekerlek izi deney aleti ve yorulma deney aleti ile yapılan deneysel çalışmalar sonucunda, tüm karışımlar için, başarılı sonuçlar elde edilmiştir.

Yol inşaatları çalışmasında, hatalı imalatlar sonucu ortaya çıkan atık asfalt miktarı da oldukça fazladır. Özellikle BSK'nın yola serilmesi aşamasında herhangi bir teknik veya başka sebeplerden kaynaklanan zaman kaybı, karışımın soğumasına neden olmakta, soğumuş olarak yola serilen karışım istenilen mukavemeti sağlayamamakta ve hatalı imalat olarak tekrar sökülmesi gerekmektedir. Bu çalışmanın amacı, hatalı imalat sonucu ortaya çıkan atık BSK'dan elde edilen geri dönüştürülmüş agregaların performansını belirlemektir. $\mathrm{Bu}$ amaçla, agregalar önce ekstraksiyon yöntemi ile bitümden ayrıştırılmıştır. Ayrıştırılan agregalara elek analizi ile boyutlandırılmış, agrega gradasyonundaki değişimi belirlenmiştir. Daha sonra geri kazanılan agregalar ile daha önce hiç kullanılmamış kalker ve bazalt kökenli agregalar soyulma mukavemeti, parçalanma direnci, yassılık indeksi ve metilen mavisi deneylerine tabi tutulmuş, elde edilen performanslar birbirleri ile karşılaştırılmıştır.

\section{MATERYALVE METOT}

\subsection{Materyal}

\subsubsection{Numune Temini}

Gerçekleştirilen deneysel çalışmada, Antalya ilinde yapımı devam eden bir yol şantiyesinden numuneler temin edilmiştir. Bitümlü temel tabakasının inşaatı sonrasında, yoldan yolun performansını test etmek amacı ile belli bir kesimde 300x210 mm, boyutlarında silindir numuneler olarak karotla alınmış, yapılan testler sonucunda imalatın hatalı olduğu belirlenmiş ve tabaka yoldan sökülerek tekrar imalat gerçekleştirilmiş̧tir. Şekil 2'de, sökülen bitümlü temel tabakası ve yoldan alınan karot numuneleri görülmektedir.
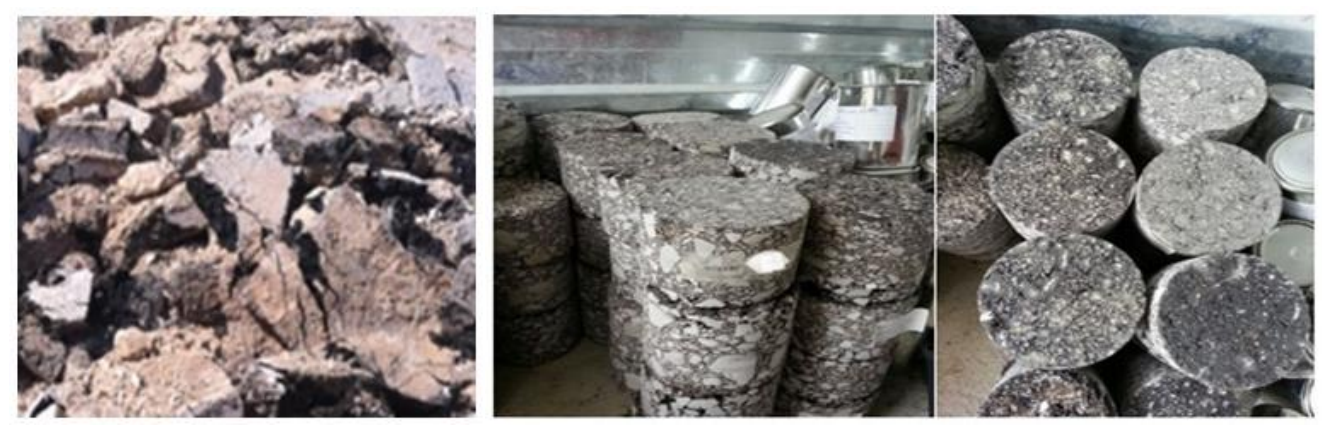

Şekil 2. Hatalı imalat nedeni ile sökülen bitümlü temel tabakası ve alınan karot numuneleri

Yolun performansının kontrolü aşamasında yoldan alınan 20 adet silindir karot numunesi de Akdeniz Üniversitesi Mühendislik Fakültesi İ̉şaat Mühendisliği Yol Üstyapıları laboratuvarına getirilmiş, silindirler parçalanarak 2-2,5 kg'llk numune gruplarına ayrılmış, buradan elde edilecek agregaların performanslarının test edilmesi amacı ile ekstraksiyon (ayrıştırma) işlemi başlatılmıştır. Ayrıştırma işlemi $4000 \mathrm{~g}$ kapasiteli cam ekstraktör ile gerçekleştirilmiştir. Şekil 3'te, cam ekstraktör ile yapılan ayrıştırma işlemi ve elde edilen geri dönüştürülmüş agregalar görülmektedir. Çözücü olarak trikloretilen kullanılmıştır. Karışımdaki maksimum dane çapına göre uygun miktardaki malzeme filtre kağıdına yerleştirilerek tel sepet içine konulmuştur. Yaklaşık 3-4 saat sonucunda her bir numune grubunun ayrıştırılması tamamlanmıştır. Ayrıştırılan numunelere elek analizi yapılmış, elde edilen sonuçlara göre her bir silindir numunesine ait gradasyon eğrisi çizilmiştir. 


\section{S. KÖFTECI}

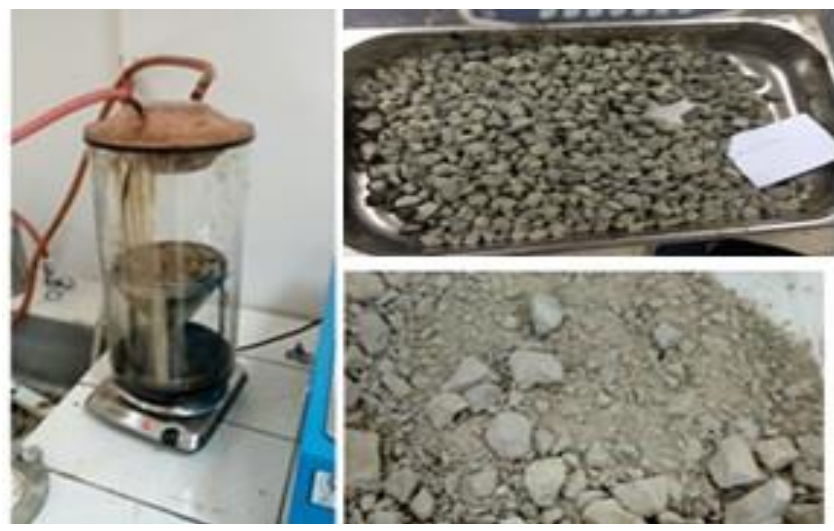

Şekil 3. Ayrıştırma işlemi, deneysel çalışmalarda kullanılan yeni agrega ve geri dönüştürülmüş agrega

\subsubsection{Elek Analizi}

Elek analizi, standart kare gözlü elekler ile, karışım gradasyonunu belirlemek amacı ile yapılmaktadır. Gradasyon, BSK'yı oluşturan agregaların boyutsal dağılımını göstermektedir. Eğer bir karışım içerisindeki agregalar hemen hemen aynı boyutta ise, bu karışım zayıf gradasyonlu olarak tanımlanır. Eğer agregaların boyutsal dağılımı geniş bir aralıkta ise, bu karışım iyi gradasyonlu (iyi derecelendirilmiş) olarak adlandırılır [22]. Deneysel çalışmada, ilk olarak her bir silindir numunesine ait gradasyon eğrisi çizilmiş ve agrega tanelerinin boyutlarının dağılımı belirlenmiştir. Şekil 4'te, 20 adet numuneye ait gradasyon eğrileri görülmektedir. Bir sonraki aşamada, incelenen 20 adet numunenin ortalama gradasyon eğrisi çizilmiş, elde edilen eğri, referans gradasyon eğrisinin alt ve üst limit değerleri ile karşılaştırılmıştır. BSK gradasyonunun belirlenmesinde, ülkemizde Karayolları Teknik Şartnamesindeki[1] ilgili tabakaya ait gradasyon tablolarından faydalanılmaktadır.

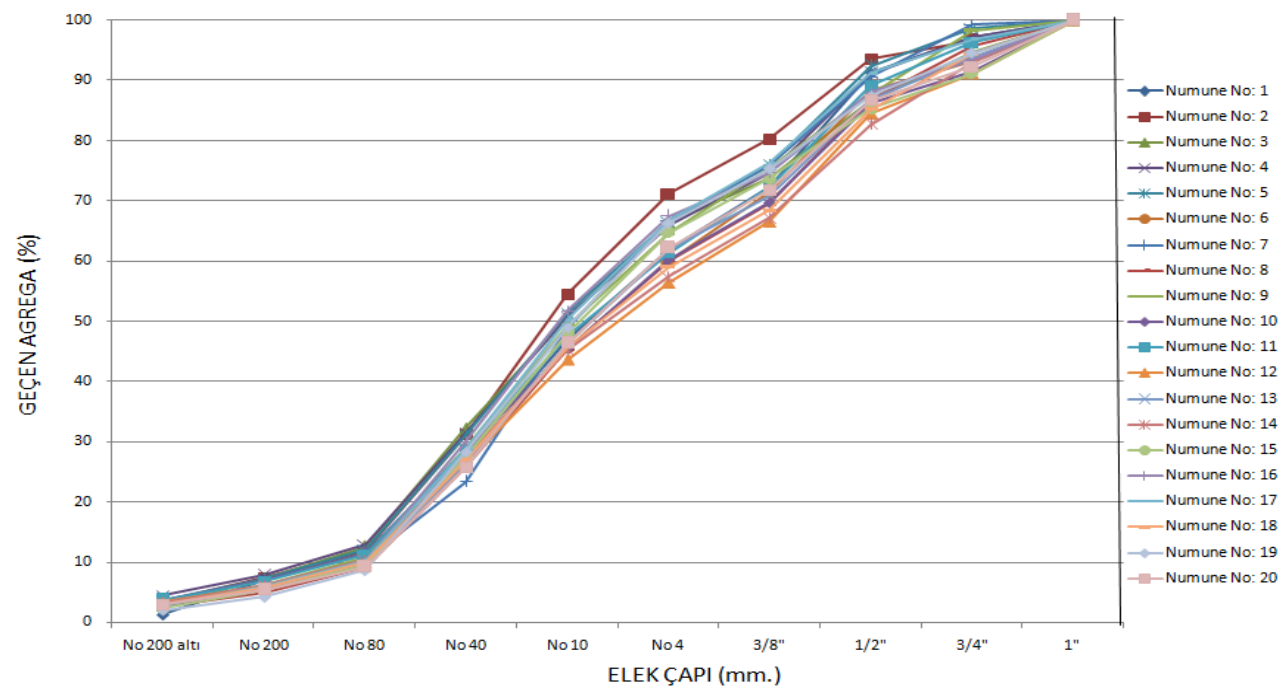

Şekil 4. 20 adet numunenin gradasyon eğrileri

$\mathrm{Bu}$ çalışmada, referans gradasyon eğrisi, Karayolları Teknik Şartnamesi’nde [1] Kısım 406'da belirtilen bitümlü temel tabakasına ait gradasyon alt ve üst limitlerine göre çizilmiştir. Geri dönüşüm yolu ile elde edilen agregaların ortalama gradasyon eğrisi incelendiğinde, referans gradasyon eğrisinin alt limit ve üst limit değerleri arasında kaldığı görülmektedir. Yani agrega boyutlarının derecelendirilmesi açısından alt ve üst limit değerleri aşılmamıştır. Ortalama gradasyon eğrisinin üst limite yakın olması ise, agregaların \% geçen miktarının bir miktar arttığını göstermektedir. Bu demektir ki, agregalar yolun serilmesi ve sıkıştırılması aşamasında bir miktar deformasyona uğramıştır yani az da olsa genel anlamda agrega çapları küçülmüştür ancak bu dane çaplarındaki bu azalma, \% geçen açısından üst limit değerleri sınırını aşmamıştır. 
BITÜMLÜ SICAK KARIŞIMLARDAN GERI DÖNÜŞÜM YOLU ILE ELDE EDILEN AGREGALARIN PERFORMANSLARININ DE GERLENDIRILMESI: DENEYSEL BIR ÇALIŞMA

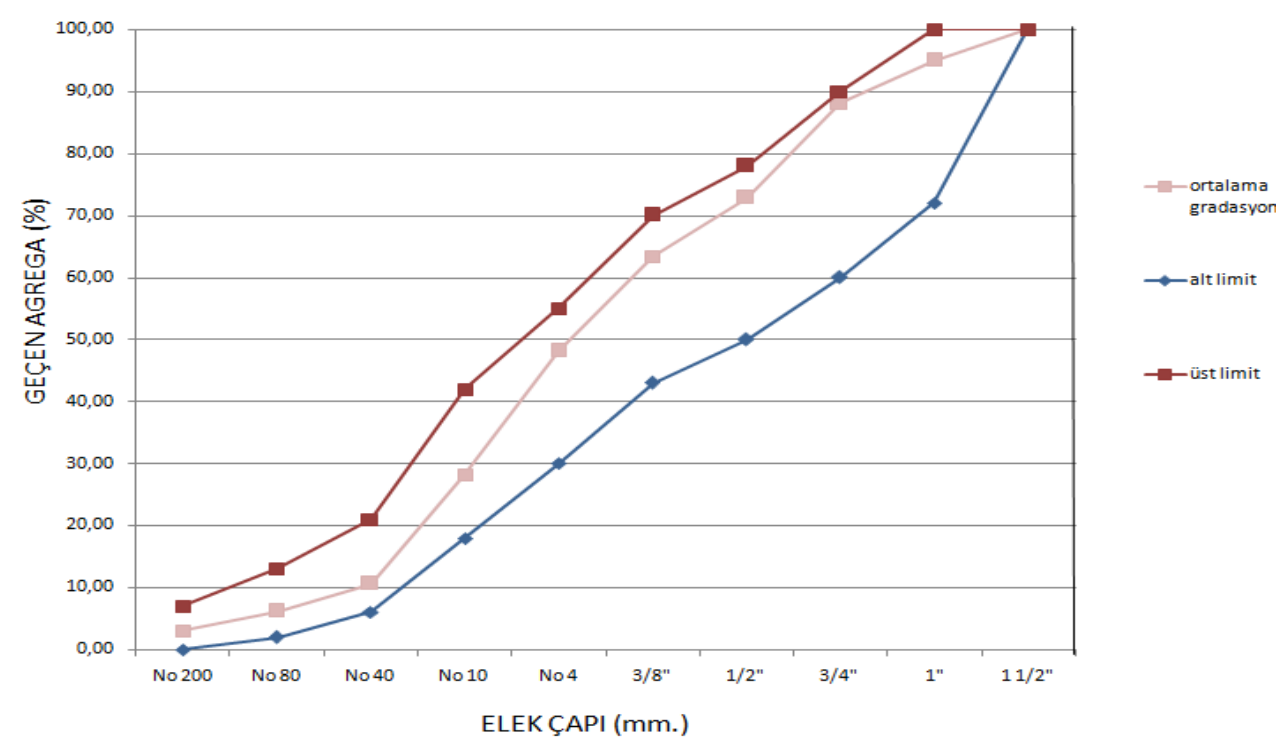

Şekil 5. Ortalama gradasyon eğrisi ve referans gradasyon eğrisi alt ve üst limit değerleri

\subsection{Metot}

Geri dönüştürülen agregaların performanslarını belirlemek için Los Angeles aşınma, yassılık indeksi, soyulma, donma-çözülme ve metilen mavisi deneyleri yapılmış, kontrol numunesi olarak da Kütahya ili çevresindeki bir taşocağından temin edilen bazalt ve Antalya ili çevresindeki bir taş ocağından temin edilen kalker agregalar kullanılmıştır. Çalışma kapsamında agregaların bitümlü sıcak karışım içerisinde kullanılabilirliği araştırıldığı için, sathi kaplamadaki agregalar için yapılan yapışma deneyi (vialit yöntemi ile) incelenen geri dönüşüm agregaları için yapılmamıştır. Agregaların kırılmışlık oranları (ağırlıkça, \%) belirlenmemiş̧ir çünkü agregaların Şekil 5'te elek analizi sonuçlarında görüldüğü gibi kırılmışlık oranları oldukça yüksektir. Bu nedenle özel olarak kırılmışlı oranları araştırılmamışıı. Cilalanma deneyi de geri dönüşüm agregalarına yapılmamıştır çünkü laboratuarımızda hızlandırılmış cilalanma makinesi mevcut değildir. Zaten geri dönüşüm agregasının yolda agreganın cilalanıp tehlike yaratma riskinin çok olduğu üst tabakalarında kullanılması düşünülmediği için, bu deney hizmet alımı yolu ile de yaptırılmamıştır. Agregaların performanslarının değerlendirildiği şartname sınır değerleri de bitümlü temel tabakasına aittir.

\subsubsection{Parçalanma Direnci (Los Angeles) Deneyi}

Parçalanma direnci (Los Angeles) deneyi, aşınma ve darbelenme etkileri sonucunda agreganın standart gradasyonunun bozulmasının ölçülmesi deneyidir [12]. Deney, ASTM C 131 deney standardına göre yapılmıştır [13]. Deney, B granülometri sınıfındaki karışımlar için yapılmıştır. 19-25 mm arası dane çapına sahip

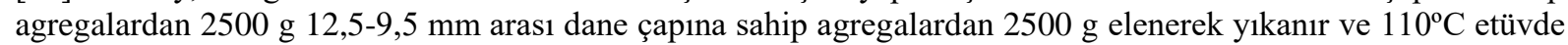
sabit ağırllğa gelinceye kadar kurutulur. Daha sonra toplam $5000 \mathrm{~g}$ numune 11 adet standart çelik küre ile beraber Los Angeles makinesine atılır, dakikada 30-33 devir olacak şekilde makineye 500 devir yaptırılır.

Gerekli devir tamamlandıktan sonra numuneler makineden çıkarılır, $1.70 \mathrm{~mm}$ elekten elenir, elek üstünde kalan malzeme yıkanır ve $110^{\circ} \mathrm{C}$ etüvde sabit ağırlığa gelinceye kadar kurutulur. Aşınma kaybı (1) numaralı formül ile hesaplanmaktadır. Bu formülde, AK aşınma kaybı yüzdesini, $G_{1}$ numunenin kuru ilk ağırlı̆̆ını ( $g$ ), $G_{2}$ ise numunenin kuru son ağırlığını (g) göstermektedir.

$$
A K=\frac{G_{1}-G_{2}}{G_{1}} \times 100
$$

\subsubsection{Soyulma Deneyi}

Asfalt kaplamalarda meydana gelen bozulmaların bir kısmı, suyun aşındıııcı etkisi altında agreganın yapışma kabiliyetini kaybetmesinden yani kaplamanın soyulmasından kaynaklanmaktadır. Soyulma, suyun ve trafiğin aşındırıcı etkisi altında bağlayıcı maddenin agreganın üzerinden ayrılması demektir [14]. Deney, TS-EN 12697- 


\section{S. KÖFTECI}

11 deney standardına göre yapılmıştır [15]. Deneyde 9,5 mm-6,5 mm arası dane çapına sahip agregalar elenerek saf su ile yıkanır ve $110^{\circ} \mathrm{C}$ etüvde sabit ağırlığa gelinceye kadar kurutulur. Kurutulan agregalar desikatöre alınarak hava ile teması kesilir. $100 \mathrm{~g}$ 1sıtılmış agrega 1sıtılmış behere konulur. Üzerine $5 \mathrm{~g}$ bitüm eklenir ve homojen bir karışım elde edilinceye kadar karışım ısıtılmış cam bagetle sıcak kum havuzu üzerinde karıştırılır. Elde edilen karışım $10 \mathrm{~cm}$ çapında petri kaplara eşit miktarlarda dökülerek 2 adet numune elde edilir. Numuneler oda sıcaklığında soğuyuncaya kadar bekletilir. Daha sonra petri kapları, yüzeyleri tamamen su ile kaplanacak şekilde içi saf su ile dolu tepsilere yerleştirilir. Tepsinin üzeri örtülür ve numuneler $60^{\circ} \mathrm{C}$ etüvde 24 saat bekletilir. Ertesi gün numunelerin üzerindeki kirlenmiş su boşaltılır. Daha net bir görüntü elde etmek için tekrar üzerlerine yeni saf su ilave edilir. Yandan gelen 1 şı yardımı ile agrega yüzeyleri incelenir ve soyulma miktarları belirlenir.

\subsubsection{Yassılık İndeksi Deneyi}

Esnek yol üstyapılarında kullanılan agreganın şekli, belirli bir yassılık değerini geçmemek şartı ile önemsenmez [16]. Bir agreganın yassı olarak tanımlanması için, kalınlığının nominal boyutunun 0.6'sından daha küçük olması gereklidir. Yassılık indeksi deneyine, yassılık değerini belirlemek için özel elekler kullanılmaktadır. Deney, BS 812 standardına göre gerçekleştirilmiştir [17]. Deneyi yapılacak üstyapı tabakasındaki dane çaplarına göre, $6,3 \mathrm{~mm}$ 'den büyük, $63 \mathrm{~mm}$ 'den küçük olan agregalar için, her elek aralığına göre standartta belirtilen miktarlarda malzeme numune olarak alınır. Her bir numune grubundaki agregalar, özel yassılık indeksi şablonunda kendi dane çapını gösteren açıklıktan elle tek tek geçirilir. Her bir elek aralığına göre ilgili açıklıkta geçen ve geçmeyen numunelerin ağırlıkları belirlenir. $G_{1}$ deneye alınan toplam malzeme ağırlığını(g), $G_{2}$ deneyde belirlenen yassı malzeme ağırlığını (g) göstermek üzere, yassı dane yüzdesi (YSY) aşağıdaki formüle göre hesaplanır:

$$
Y S Y=\frac{G_{2} x 100}{G_{1}}
$$

Her bir elek aralığına ait düzeltilmiş yassı dane yüzdelerinin toplamı, yassılığı araştırılan üstyapı tabakasının yassılık indeksi değerini verir.

\subsubsection{Donma-Çözülme deneyi}

Agreganın olumsuz hava koşulları nedeni ile zayıflayıp darbelenmelere karşı dayanıksız hale gelmesi üstyapının dayanımını da düşürür. Soyulma, oluklanma gibi esnek üstyapıda meydana gelen bozulmalar, asfalt karışımını oluşturan agregaların olumsuz hava koşulları karşısında durabilitelerinin düşük olmasından kaynaklanmaktadır[18]. Agreganın olumsuz hava koşulları altında, donup çözülerek dayanımını ne derecede kaybedeceği, donma-çözülme deneyi ile belirlenir. TS EN 1367-2'ye[19] göre, dane çapları 10-14 mm arasında olan agregalardan, deneyi yapılacak üstyapı tabakasını temsil eden her elek aralığı için şartnamede belirtilen miktarlarda agrega alınır, yıkanır ve $110^{\circ} \mathrm{C}$ etüvde sabit ağırlığa gelinceye kadar kurutulur, ağırlığı tartılı $\left(\mathrm{AG}_{1} ; \mathrm{g}\right)$ ve tel sepete konulur. Hazırlanan magnezyum sülfat çözeltisinin içerisine sepetle beraber agregalar yerleştirilir. Agregaların üstü, en az $2 \mathrm{~cm}$ çözelti ile kaplanmalıdır. Agregalar, çözeltinin sıcaklığı $(20 \pm 2)^{\circ} \mathrm{C}$ olacak şekilde, çözelti içinde $(17 \pm 0,5)$ saat bekletilir. Bu süre sonunda agregalar çözeltiden çıkarılır, sular süzüldükten sonra $110^{\circ} \mathrm{C}$ etüvde 24 saat bekletilir. Daha sonra, donma çözülmeyi temsil eden daldırıp kurutma işlemi beş defa tekrarlanır. Beşinci işlemin sonucunda agregalar yıkanır ve kurutulur. $10 \mathrm{~mm}$ 'lik elekten elenir ve elek üstünde kalan agregaların ağırlıkları $\left(\mathrm{AG}_{2} ; \mathrm{g}\right)$ tartılır. Agregalarda meydana gelen ağırlık kaybı (AK) şu şekilde hesaplanır:

$$
A K=\frac{100\left(A G_{1}-A G_{2}\right)}{A G_{1}}
$$

\subsubsection{Metilen Mavisi Deneyi}

Agregaların bir kısmı, kendilerini asfalt kaplama karışımları içerisinde olumsuz hale getiren bir takım zararlı maddeler içerebilmektedir [20]. Kil, silt gibi zararlı madde olarak isimlendirilen çok ince malzemeler, bitümlü sıcak karışımın performansını olumsuz yönde etkilemektedir. Kaba agreganın temizliği büyük ölçüde doğrudan yıkama ile sağlanabilmektedir. İnce agregada ise, doğrudan yıkama imkanı mevcut olmadığı için, çok ince zararlı madde miktarı ancak metilen mavisi deneyi ile belirlenebilmektedir. TS EN 933-9 [21] şartnamesinde 
metilen mavisi deneyi ile 0-2 $\mathrm{mm}$ aralığında dane çapına sahip agregalardaki ince malzeme oranı tespit edilir. $200 \mathrm{~g}$ ağırlığındaki numune $110^{\circ} \mathrm{C}$ etüvde sabit ağırlığa gelinceye kadar kurutulur ve oda sıcaklığında soğumaya bırakılır. $500 \mathrm{~mL}$ damıtık su içerisine kurutulan numune eklenir ve $600 \pm 60$ devir/dakikada 5 dakika karıştırılır. Sonra behere $5 \mathrm{~mL}$ metilen mavisi çözeltisi eklenir. Daha sonra beherdeki malzeme $400 \pm 40$ devir/dakika hızla en az 1 dakika karıştırılır ve süzgeç kağıdına karışımdan bir damla damlatılır. İlk çözeltiden sonra hale (damlanın etrafında açık mavi tonda yayılma) meydana gelmezse, $5 \mathrm{~mL}$ daha çözelti karışıma ilave edilir ve 1 dakika daha karıştırmaya devam edilir. Halenin görülmesine kadar boya ilave edilmesine ve karıştırılmaya devam edilir. Hale görüldükten sonra, ilk dört dakikada kaybolursa $5 \mathrm{~mL}$ daha boya çözeltisi ilave edilir ve tekrar deneme yapılır. Hale beşinci dakikada kayboluyorsa, sadece $2 \mathrm{~mL}$ boya çözeltisi ilavesi yapılır ve tekrar süzgeç kâğıdında karışım damlatılır. Hale 5 süzgeç kâğıdında 5 dakika varlığını koruyana kadar leke deneyi yapılmaya devam edilir. Metilen mavisi değeri şu şekilde hesaplanır:

$$
M M=\frac{V M}{M N} \times 10
$$

Burada MM metilen mavisi değerini $(\mathrm{g} / \mathrm{kg})$, VM karışıma ilave edilen boya çözeltisinin toplam hacmini $(\mathrm{ml})$, MN'deney numunesinin ağırlığını (g) göstermektedir.

\section{BULGULAR VE TARTIŞMA}

\subsection{Parçalanma Direnci (Los Angeles) Deneyi}

Parçalanma direnci deneyi, agregaların tekrarlı trafik yüklerinden kaynaklanan darbelenmelere karşı dayanımlarını ölçmek için yapılmaktadır. Deneysel çalışmada kullanılan cihaz ve agregalar Şekil 6'da görülmektedir.

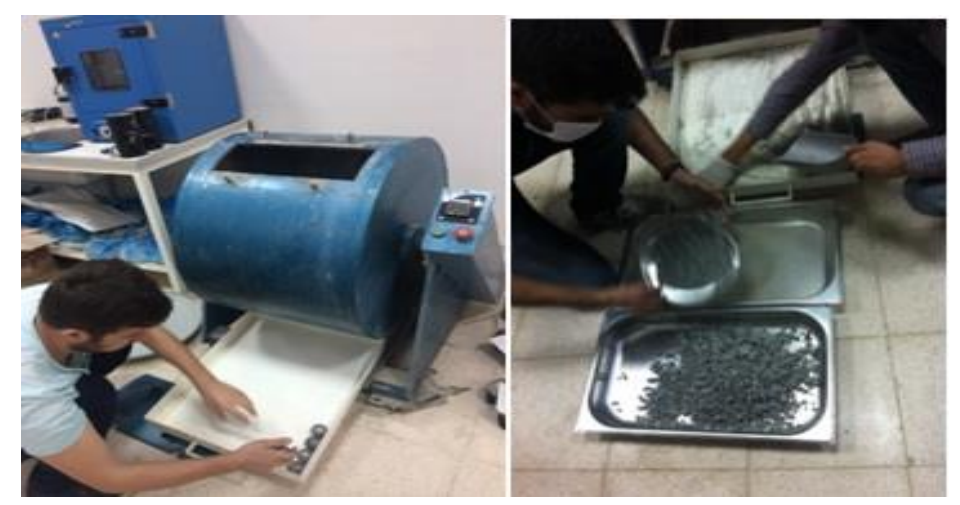

Şekil 6. Los Angeles deney cihazı ve deney sonucu elde edilen agregalar

Tablo 1'de de, geri dönüşüm agrega, kalker ve bazalt için yapılan deney sonuçları görülmektedir. Gerçekleştirilen deneysel çalışmalardan elde edilen sonuçların karşılaştıııldı̆̆ı limit değerleri, Karayolları Teknik Şartnamesi 2013'de [1] karayollarında bitümlü temel tabakasına ait dizayn kriterlerinin anlatıldığı Kısım 406'daki tablolardan alınmıştır. Parçalanma direnci (Los Angeles) değeri, şartnamede kaba agreganın özellikleri tablosunda maksimum \%30 olarak belirtilmiş̧ir. Deneysel çalışma sonucunda, her üç malzemenin parçalanma direnci değerlerinin, bu sınır değerden aşağıda olduğu belirlenmiş̧ir. Geri dönüşüm malzemesinde parçalanma direnci değeri diğerlerine göre bir miktar fazla çıkmıştır. Bu durumun sebebinin, geri dönüşüm agregasının ayrıştırma işlemi sırasında buharlaşıp tekrar yoğunlaşan trikloretilen ile yıkanmasıdır. Burada her ne kadar uçucu da olsa çözücü bir kimyasal madde ile temasın, malzemenin dayanımını biraz düşürdüğü düşünülmektedir.

Tablo 1. Agregalar için parçalanma direnci değerleri ve şartname sınır değeri

\begin{tabular}{|c|c|c|c|}
\hline $\begin{array}{c}\text { Geri dönüşüm } \\
\text { malzeme }\end{array}$ & Kalker & Bazalt & Şartname \\
\hline$\% 27,6$ & $\% 22,4$ & $\% 10,81$ & $\leq \% 30$ \\
\hline
\end{tabular}




\section{S. KÖFTECI}

\subsection{Soyulma Deneyi}

Soyulma deneyi, agreganın bitüm tarafından sarılabilirliğinin bir ölçüsüdür. Deney çalışması ve deney sonucu elde edilen numunelerin görselleri Şekil 7'de görülmektedir. Soyulma deneyi sonuçları, karayolu sektöründe çalışan ve akademisyenlerden oluşan 4 kişi tarafından yorumlanmış ve belirlenen soyulma yüzdesi aralıkları Tablo 2'de gösterilmiştir.

Tablo 2. Agregalar için soyulma yüzdesi değerleri ve şartname sınır değeri

\begin{tabular}{|c|c|c|c|}
\hline $\begin{array}{c}\text { Geri dönüşüm } \\
\text { malzeme }\end{array}$ & Kalker & Bazalt & Şartname \\
\hline$\% 60-65$ & $\% 75-80$ & $\% 75-80$ & $\geq \% 60$ \\
\hline
\end{tabular}

Soyulma mukavemeti değeri, Karayolları Teknik Şartnamesi 2013'de[1] \% bitümle kaplı yüzey $\left(24\right.$ saat $60^{\circ} \mathrm{C}$ suda bekletmeden sonra) minimum \%60 olmalı şeklinde belirtilmiştir. Kalker ve bazalt, yapılan deneysel çalışma sonucunda hemen hemen aynı performansı göstermiştir. Geri dönüşüm malzemesindeki performans, beklenen standardı karşılamaktadır ancak bir miktar düşüktür. Soyulma deneyinde geri dönüşüm agregasında en düşük değerin çıkmasının nedeni, ayrıştırma işlemi sırasında agreganın triklor etilen ile temas etmesidir. Her ne kadar soyulma deneyinde agregalar iyice yıkansa ve triklor etilen uçucu bir malzeme olsa da, etkilerinin agrega üzerinde kaldığı düşünülmektedir. Geridönüşüm agregasının serilme ve sıkıştırılması sırasında kısmen kırılarak pürüzlü bir yüzey elde edilmesinin ise, soyulma açısından avantaj oluşturduğu düşünülmektedir.

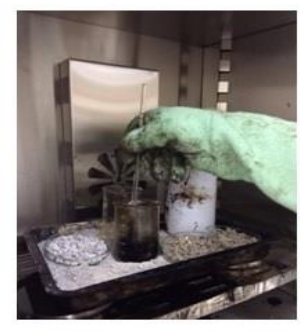

(a)

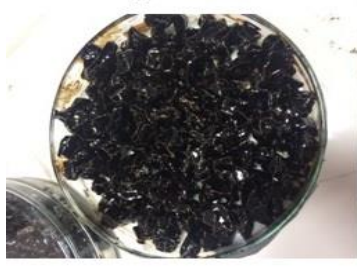

(c)

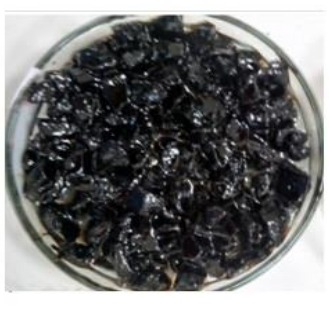

(b)

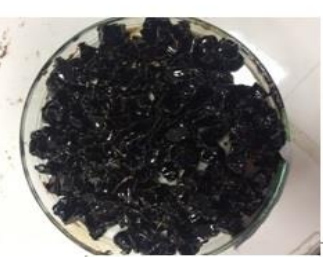

(d)

Şekil 7. Soyulma deneyi çalışması ve kalker, bazalt ve geri dönüşüm agregaya ait deney kapları

\subsection{Yassılık İndeksi Deneyi}

Yassı agregalar, trafik yükleri altında kolayca kırılabildiği için, bitümlü sıcak karışımın asıl taşıyıcı kısmını oluşturan agregaların içerisinde, belirli bir orandan fazla yassı agrega bulunması istenmez. Agrega performansında önemli bir gösterge olan yassılık indeksinin 3 değişik grup agregada incelenmesi için, Şekil 8'de resimleri görülen yassılık indeksi deneyi, yassılık eleği yardımı ile yapılmıştır. Şartname sınır değeri ve deney sonuçları da Tablo 2'de görülmektedir. Yassılık indeksi sınır değeri, Karayolları Teknik Şartnamesi 2013'de [1] bu oran bitümlü temel tabakası için maksimum \%30 olarak belirtilmiştir. Tablo 3'deki sonuçlar incelendiğinde, her üç agrega için de şartname sınır değerinin aşılmadı̆̆ı görülmektedir.

Bir malzeme ne kadar kırılma etkisine maruz kalır ise, köşegen yapısı o kadar artar. Bazalt sert bir malzemedir. Konkasörde kırma işlemi ile yol agregası olarak kullanılabilecek boyutlara getirilmiştir ama, bazalt kalkere göre daha dayanıklı olduğu için çok fazla köşegenli bir yapı oluşmamıştır. Bu nedenle de yassı malzeme ağırlığı daha fazla çıkmıştır. Geri dönüşüm malzemesinde ise, malzemenin yola serilmesi ve sıkıştırılması aşamasında daha fazla bir kırılma meydana gelmiştir. Zaten Şekil 5'te agregalara ait gradasyon eğrisi incelenirse, eğrinin üst limite yaklaştığı yani agregaların serme ve sıkıştırma işlemi aşamasında bir miktar tahribata uğrayarak dane 
çaplarının küçüldüğü görülmektedir. Yassılık indeksi seneyi sonucu da, meydana gelen bu tahribatı destekler niteliktedir. Yani agrega tahribata uğraması sonucu daha köşeli hale gelmiş, bu da yassı dane miktarını azaltmıştır.

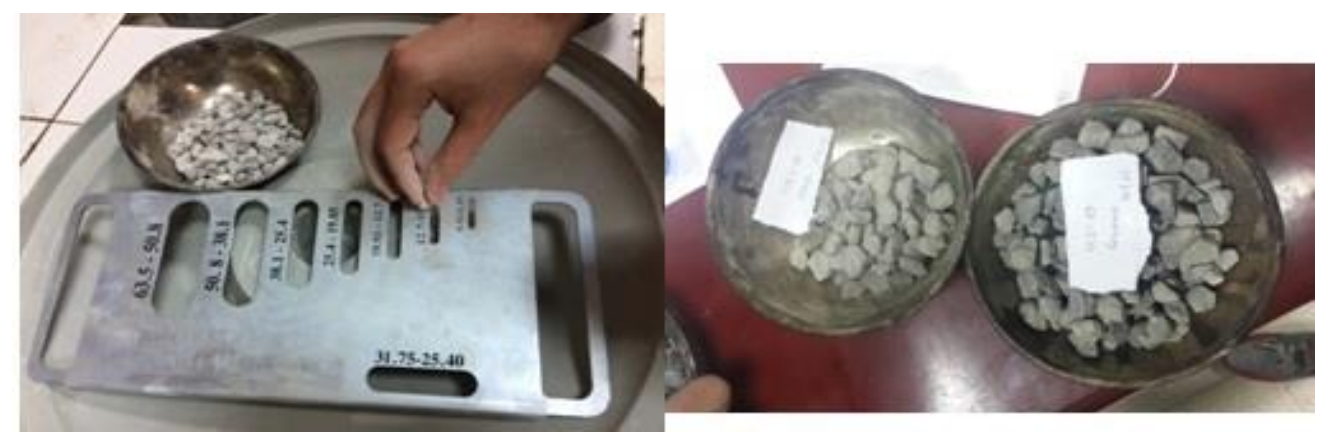

Şekil 8. Yassılık indeksi deneyi çalışması ve deneyde kullanılan agregalar

Tablo 3. Yassılık indeksi deneyi sonuçları ve şartname sınır değeri

\begin{tabular}{|c|c|c|c|}
\hline $\begin{array}{c}\text { Geri dönüşüm } \\
\text { malzeme }\end{array}$ & Kalker & Bazalt & Şartname \\
\hline 14,40 & 18,27 & 21,27 & $\leq \% 30$ \\
\hline
\end{tabular}

\subsection{Donma-Çözülme Deneyi}

Donma-çözülme deneyi, çözeltinin sıcaklığının sabit tutulmasını sağlayan 1sıtmalı-soğutmalı bir su banyosu ile genellikle yapılmaktadır ancak bizim laboratuvarımızda bu cihaz henüz mevcut değildir. Bu nedenle farklı bir yöntem denenmiştir. Deneysel çalışmada, çözelti sıcaklığını $20 \pm 2^{\circ} \mathrm{C}$ 'de sabit tutmak için, hiç penceresi olmayan bir odada klima ile ortam sıcaklığı sabit hale getirilmiştir. Daha sonra çözelti sıcaklığı, deneyden bir gün önce kontrol edilmeye başlanmıştır. Elde edilen değerlere göre, ortam sıcaklığı çözeltinin şartname limit sıcaklık değerleri arasında olmasını sağlayacak şekilde ayarlanmıştır. Deney süresince ortam sıcaklığında bir değişme olup olmadığı sık sık kontrol edilmiştir. Hava tesirlerine karşı dayanıklılık, ( $\mathrm{MgSO}_{4}$ ile kayıp) Karayolları Teknik Şartnamesi 2013'de [1] maksimum \%18 olarak belirtilmiştir. Deneysel çalışma sonucu elde edilen değerler incelendiğinde, bazaltın en iyi sonucu verdiği görülmektedir. Zaten bazalt sert ve dayanıklı bir malzeme olduğu için, bu beklenen bir sonuçtur. Geri dönüşüm malzemesindeki ağırlık kaybı, kalkere oldukça yakındır ve en önemlisi şartname sınır değerinde oldukça uzaktır. Yani hava tesirlerine karşı dayanıklılık açısından agregada geri dönüşüm sonucu meydana gelen kayıp oldukça azdır.

Tablo 4. Donma-çözülme deneyi sonuçları ve şartname sınır değeri

\begin{tabular}{|c|c|c|c|}
\hline $\begin{array}{c}\text { Geri dönüşüm } \\
\text { malzeme }\end{array}$ & Kalker & Bazalt & Şartname \\
\hline$\% 13$ & $\% 12$ & $\% 9$ & $\leq \% 18$ \\
\hline
\end{tabular}

\subsection{Metilen Mavisi Deneyi}

Karayolları Teknik Şartnamesi 2013'de [1], ince agreganın özellikler tablosunda, metilen mavisi değeri (MM), ince agreganın 0/2 mm'lik kısmı için en fazla 2 olarak belirtilmiştir. Aynı tabloda, MM değeri, öğütülmüş mağmatik agreganın 0/2 mm.'li kısmına 3,5 olarak belirtilmiştir. Bazalt bir magmatik kayaçtır. Bu nedenle, MM değerinin 3,5'a göre değerlendirilmesi gerekmektedir. Kalker ve kalker kökenli geri dönüşüm agrega ise, tortul kayaç türündendir yani MM değeri 2,5'e göre değerlendirilmelidir. Şekil 9'da, metilen mavisi deneyinde numunenin hazırlanması ve süzgeç kâğıdına damlatılması işlemi görülmektedir.

Metilen mavisi deneysel çalışmasının sonuçlarının gösterildiği Tablo 5 incelenirse, geri dönüşüm malzeme ile kalkerin MM değerini verdiği görülmektedir. Bu taşlar, aynı ocaktan elde edildiği için bu beklenen bir sonuçtur. Bazaltın ise MM değeri 3,0'dür. Bazalt magmatik kökenli bir kayaç olduğu için, bu değer şartname sınır değerlerinin içindedir yani deneysel çalışmaya alınan tüm agregalar, ince malzeme içeriği açısında, BSK içinde kullanilmaya uygundurlar. 


\section{S. KÖFTECI}
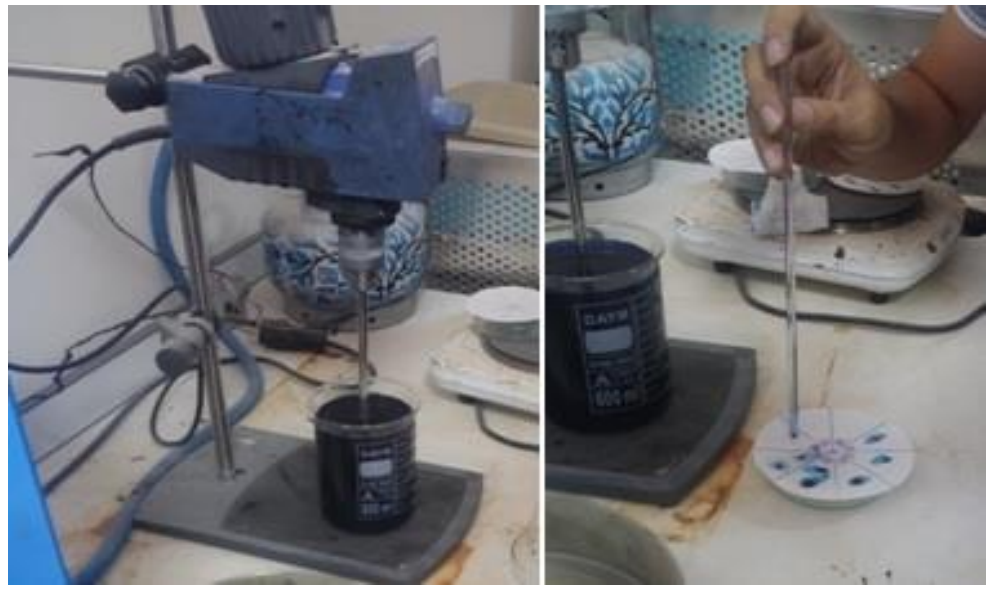

Şekil 9. Metilen mavisi deneyi işlemleri

Tablo 5. Metilen mavisi deneyi sonuçları ve şartname sınır değeri

\begin{tabular}{|c|c|c|c|}
\hline $\begin{array}{c}\text { Geri dönüşüm } \\
\text { malzeme }\end{array}$ & Kalker & Bazalt & Şartname \\
\hline 1,5 & 1,5 & 3,0 & $\begin{array}{c}\leq 2,0 \text { (İnce agrega) } \\
\leq 3,5 \text { (Öğütülmüş mağmatıik kayaç) }\end{array}$ \\
\hline
\end{tabular}

\section{SONUÇLAR}

Bitüm viskoelastik bir malzemedir, yani bitümün davranışı, sıcaklığa bağlı olarak değişmektedir. Bitümün bağlayıcı olarak kullanıldığı bitümlü sıcak karışım da bitümün bu özelliğinden dolayı sıcaklığa karşı hassas kompozit bir malzemedir. Karayolunda bitümlü sıcak karışımın yola serilmesi ve sıkıştırılması aşamasında, sıcaklık değerlerine çok dikkat edilmesi gereklidir. Aksi taktirde, serilen yol çok kısa zamanda bozulmaya başlar. $\mathrm{Bu}$ hassasiyetten dolayı, bitümlü sıcak karışımın üretim tesisinden çıkarılması, serilmesi ve sıkıştırılması aşamalarına ait sıcaklık sınır değerleri ilgili şartnamelerde belirtilmiştir. Yolun inşası sırasında, özellikle gerekli sıcaklık değerlerine uyulamaması veya başka nedenlerden dolayı, hatalı imalatlar ortaya çıkmaktadır. Hatalı imalatlar tespit edildikten sonra yol tabakası sökülmekte, henüz çok yıpranmamış agregalardan oluşan atık bir malzeme ortaya çıkmaktadır. Bu çalışmanın amacı, bu şekilde elde edilen geri dönüşüm agregalarının performanslarını ve bu performanslara bağlı olarak tekrar kullanılabilirliğini belirlemektir.

Gerçekleștirilen deneysel çalışmaların sonucunda, geri dönüșüm agregalarının performanslarını bir miktar kaybettiği görülse de, bu agregalar hiç kullanılmayacak seviyede değildirler. Aksine şartname limit değerlerinin oldukça üzerinde dayanım özellikleri gösterdikleri için, tekrar kullanılabilir durumdadırlar. Bu çalışmada, asfalt karışımdan elde edilen agregaların performansları analiz edilmiştir. Literatürde, hem asfalt hem de beton karışımlarından elde edilen agregaların performansları ile ilgili çalışmalar mevcuttur. Zhang ve ark. [23], geri dönüşüm beton agregasının asfalt karışımına etkisini inceledikleri çalışmalarında, geri dönüşüm agregasına performans deneyleri uygulamıştır. Deneysel çalışmada, geri dönüşüm agregasını, üç farklı elek aralığında parçalanma direnci deneyine tabi tutmuşlardır. Deneysel çalışma sonucunda, ortalama $\% 13$ değerinde buldukları parçalanma direnci değerini JTGE42-2005 numaralı Çin standardında sınır değer olan \%30 ile karşılaştırmışlar ve geri dönüşüm agregasının performansını bu çalışmadaki gibi yüksek belirlemişlerdir. Geri dönüşüm asfalt kaplamasının performansını agrega ve bağlayıcı açısından birbirinden bağımsız olarak raporunda değerlendiren Han ve ark. [24], geri dönüşüm agregasının yassılık indeksi değerini \%2,6 olarak belirlemişlerdir. Bu değeri, Süperpave şartname sınır değeri olan \%10 ile karşılaşıırdıklarında, yassılık indeksi açısından agreganın gerekli koşulları sağladığını belirmişlerdir.

Esnek yol üstyapısı tabakalı bir yapıya sahiptir. Tekerleklerin tekrarlı dingil yükleri ile yol yüzeyinin temasının gerçekleştiği en üst aşınma tabakasındaki agregaların performanslarının en üst seviyede olması beklenmektedir. $\mathrm{Bu}$ tabakadan aşağıya doğru inildikçe, agregalardan beklenen performans limitlerinde bir miktar azalma kabul edilebilir, çünkü trafik yükü ile doğrudan bir etkileşim söz konusu değildir. Bu nedenle, Karayolları Teknik Şartnamesi 2013'de [1] geri dönüşüm malzemenin yol inşaatında tekrar kullanılması şartlarının açıklandığı Kısım 414'te, kazınmış asfaltın yüzey (aşınma) tabakası yapımında kullanılamayacağı açıkça belirtilmiştir. 
Ayrıca yeni yapılacak bitümlü sıcak karışım imalatında da kullanılabilecek kazınmış asfalt miktarı en fazla \%25 ile sınırlandırılmıştır. Tabi burada ifade edilen, kazınmış bitüm ve agrega karışımıdır. Yani bitüm ve agreganın kullanım ömrü boyunca ve kazınması aşamasındaki yıpranması göz önüne alınarak böyle bir sınırlandırma yapılmıştır. Yine de buradan yola çıkarak, burada yapılan deneysel çalışmaların sonuçlarını da göz önüne alarak geri dönüşüm agregasının doğrudan trafik yüklerine maruz tabakalarda kullanılmasının, agregada meydana gelen kısmi yıpranmadan dolayı sakıncaları olabilir. Ancak hatalı imalat sonucu ortaya çıkan geri dönüşüm agregalarının yüzeyden daha uzak alt tabakalarda kullanılmalarının sakıncası yoktur. Geri dönüşüm agregası üzerine yapılacak gelecekteki çalışmalarda, hatalı imalat sonucu elde edilen agregaların yanı sıra, trafik yüküne doğrudan maruz kalmış üstyapının daha üst kısımlarındaki agregaların da performansının değerlendirilip, yeniden kullanılabilirliğinin araştırılması önerilmektedir.

\section{KAYNAKLAR}

[1] KARAYOLLARI GENEL MÜDÜRLÜĞÜ YAYINLARI, Karayolları Teknik Şartnamesi, Ankara, Türkiye, 2013.

[2] WALLACE, H.A., MARTIN, J.R., Asphalt Pavement Engineering, McGraw-Hill Inc., U.S.A., 1967.

[3] http://www.eapa.org/ (erişim tarihi 15.12.2016).

[4] http://www.medyakesan.com.tr/gundem/saros-korfezindeki-tas-ocaklari-kanser-gibi-h3451.html (erişim tarihi 10.01.2017)

[5] GÜRER, C., AKBULUT, H., KÜRKLÜ, G., “İnşaat Endüstrisinde Geri Dönüşüm ve Bir Hammadde Kaynağı Olarak Farklı Yapı Malzemelerinin Yeniden Değerlendirilmesi”, 5. Endüstriyel Hammaddeler Sempozyumu, 2836. İzmir, Türkiye, 2004.

[6] MANNAN, U. A., ISLAM, R. M.D., TAREFDERS, R. A., "Effects of Recycled Asphalt Pavements on the Fatigue Life of Asphalt under Different Strain Level Sand Loading Frequencies”, International Journal of Fatigue, 78, 7280, 2015.

[7] ZAUMANIS, M., RAJIB, B.M., FRANK, R., "100 \% Recycled Hot Mix Asphalt: A Review and Analysis", Resources, Conservation and Recycling, 92, 230-245, 2014.

[8] PAULIKAKOS, L.D., SANTOS S., BUENO M., KUENTZEL S., HUGENER, M., PARTL, M.N., "Influence of Short and Long Term Aging on Chemical, Micro Structural and Macro-mechanical Properties of Recycled Asphalt Mixtures", Construction and Building Materials, 51, 414-423, 2014.

[9] GUO, N., YOU, Z., ZHAO, Y., TAN, Y., DIAB, A., "Laboratory Performance of Warm Mix Asphalt Containing Recycled Asphalt Mixtures", Construction and Building Materials, 64, 141-149, 2014.

[10] ABREU, L., OLIVERIA, J.R.M., SILVA, H.M.R.D., FONSECA, P.V, "Recycled Asphalt Mixtures Produced with High Percentage of Different Waste Materials", Construction and Building Materials, 84, 230-238, 2015.

[11] HARITONOVS, R. I., KLASA, I., ZAUMANIS, M., "Hot Mix Asphalt with High RAP Content", Procedia Engineering, 114, 676-684, 2015.

[12] ÖNAL, A., KAHRAMANGIL, M., Bitümlü Karışımlar Laboratuvar El Kitabı, KGM AR_GE Dairesi Başkanlığı, KGM Yayınları, Ankara, Türkiye, 2012 .

[13] AASHTO T 96, Standard Test Method for Resistance to Degradation of Small-Size Coarse Aggregate by Abrasion and Impact in the Los Angeles Machine, Annual Book of ASTM Standarts, 1996.

[14] ILICALI, M., TAYFUR, S., ÖZEN, H., Asfalt ve Uygulamaları, İsfalt Yayınları, İstanbul, Türkiye, 2001.

[15] TS-EN-12697-11, Agrega ve Bitüm Arasındaki Bağlanmanın Tayini için Standart. Test Yöntemi, Türk Standartları, 2012.

[16] WHITEOAK, D., Shell Bitüm El Kitabı, İsfalt Yayınları, İstanbul, Türkiye, 2004.

[17] BS 812, Methods for Determination of Particle Shape: Flakiness Index”, British Standarts, 1989.

[18] WU,Y., PARKER, F., KANDHAL,K., Aggregate Toughness/Abrasion Resistance and Durability/Soundness Tests Related to Asphalt Concrete Performance in Pavements, NCAT Report No. 98-4, 1998.

[19] TS EN 1367-2, Agregaların Termal ve Bozunma Özellikleri için Deneyler Bölüm 2: Magnezyum Sülfat Deneyi, Türk Standartları, 1999.

[20] ULUÇAYLI, M., Asfalt El Kitabı, İsfalt Yayınları, İstanbul, Türkiye, 2002.

[21] TS-EN 933-9, İnce Tanelerin Tayini, Metilen Mavisi Deneyi, Türk Standartları, 2001.

[22] KREBS, R.D., WALKER, R.D., Highway Materials, McGraw-Hill Inc., U.S. , 1971.

[23] ZHANG, Z., WANG,K., LIU,H., DENG, Z., "Key Performance Properties of Asphalt Mixtures with Recycled Concrete Aggregate from Low Strength Concrete", Construction and Building Materials, 126, 711-719, 2016.

[24] HAN, J., THAKUR, S.C., CHONG, O., PARSONS, R.L., "Laboratory Evaluation of Characteristics of Recycled Asphalt Pavement in Kansas", Report No. K-TRAN:KU-09-2, Kansas Department of Transportation, Kansas State University Transportation Centre, The University of Kansas, 2011. 